\title{
Tindak Pidana Pornografi dalam Era Siber di Indonesia
}

\author{
Bambang Sudjito ${ }^{1 *}$, Abdul Majid ${ }^{2}$, Faizin Sulistio ${ }^{3}$, Patricia Audrey Ruslijanto ${ }^{4}$ \\ Fakultas Hukum Universitas Brawijaya
}

\begin{abstract}
Abstrak
Fokus isu dan/atau permasalahan pada analisis (a) hakekat pengaturan tindak pidana Pornografi di Indonesia; (b) realita putusan lembaga peradilan di Indonesia terhadap tindak pidana pornografi; dan (c) pengaturan tindak pidana pornografi dalam upaya penanggulangan pornografi diera siber di Indonesia. Penelitian dalam lingkup hukum normatif melalui pendekatan peraturan perundang undangan, kasus, dan konsep; bahan hukum dalam penelitian, antara lain Kitab Undang undang Hukum Pidana (KUHP) Indonesia; Undang Undang Nomor 44 Tahun 2008 tentang Pornografi; Undang Undang Nomor 11 Tahun 2008 tentang Informasi dan Transaksi Elektronik; dan Convention on Cyber Crime Tahun 2001, Budapest - Hungaria; teknik pengumpulan bahan hukum melalui identifikasi dan klasifikasi ketentuan hukum pornografi siber serta mengkaji berbagai literatur terkait; dan analisis bahan hukum melalui substansi tentang pornografi siber serta asas asas hukum dan kebijakan hukum dalam peraturan perundang undangan. Hasil penelitian hukum normatif bermanfaat, baik teoritis untuk pengembangan dalam keilmuan hukum pidana (pornografi/pornografi siber) serta keilmuan terkait lainnya ataupun praktis untuk penegakan hukum pidana di bidang pornografi/pornografi siber (Kepolisian, Kejaksaan, Pengadilan, dan lembaga terkait lainnya).
\end{abstract}

Kata kunci: hakekat dan realita pengaturan, tindak pidana, dan pornografi

\section{Abstract}

The focus and/or issues in the analysis are (1) facts and setting of pornography in Indonesia, (2) Indonesian judiciary sentence for crime of pornography in Indonesia, and (3) regulations related to crime of pornography in order to minimize pornography and sex crime during cyber era in Indonesia. The setting of the study is the normative legal more particularly the legislation, cases and concepts. The references are the Criminal Code, the 2008 Act number 44 about pornography, the 2008 Act number 11 about information and electronic transaction and the 2001 Budapest, Hungary Convention on Cyber Crime. The data collection techniques are identification and classification of the normative legal about pornography as well as analyses towards related literature, substantive documents about cyber pornography, law principles and policies in the legislation. The findings of the study have theoretical contribution to the body of knowledge particularly one related to penal code, pornography and cyber pornography and practical contribution for police department, court, prosecution and other related institutions to minimize pornography and sex crime.

Keywords: facts and reality, crime and pornography

\section{PENDAHULUAN}

Dinamika kehidupan masyarakat atau bangsa senantiasa sejalan dengan ilmu pengetahuan dan teknologi yang dimilikinya. Hal ini, pemanfaatan ilmu pengetahuan dan teknologi oleh masyarakat atau bangsa yang dapat dipahami melalui berbagai periode teknologi [1] yang diawali dengan periode teknologi pertanian, teknologi industri, teknologi informasi, teknologi nano, dan diakhiri dengan periode bioteknolgi.

Dinamika ilmu pengetahuan dan teknologi serta pemanfaatannya dalam kehidupan masyarakat atau bangsa, selain berdampak positif juga berdampak negatif bagi perkembangan dalam kehidupan masyarakat atau bangsa yang bersangkutan, terutama kehidupan ideologi, ekonomi, sosial, dan budaya.
Oleh karena itu, diperlukan keberadaan norma, kaidah, atau hukum yang menunjang tertib pergaulan dalam kehidupan masyarakat atau bangsa, sebagaimana adagium "ubi societas ibi ius" (anonymous). Keberadaan hukum dengan berbagai fungsinya [2], selain untuk mengubah perilaku masyarakat atau law as a tool of social engineering; juga untuk mengendalikan perilaku masyarakat yang melanggar ketentuan hukum atau law as a tool of social control.

Salah satu bentuk pemanfaatan ilmu pengetahuan dan teknologi yang berbasis teknologi informasi dan komunikasi dalam kehidupan masyarakat atau bangsa, yang dikenal dengan periode teknologi informasi. Oleh karena itu, berbagai bentuk perkembangan dalam periode teknologi informasi [3], yang meliputi

Alamat Korespondensi Penulis:

Bambang Sudjito

Email : b_djito@.ub.ac.id

Alamat : Fakultas Hukum Universitas Brawijaya 
telematika, multi media, dan teknologi informasi dan komunikasi. Walaupun demikian berbagai istilah terkandung makna yang sama, sehingga masing masing istilah tersebut disesuaikan dengan penggunaannya.

Kejahatan telematika [3] sebagai bentuk kejahatan melalui penyalahgunaan teknologi yang terkonvergensi dari komputer, media, dan informasi, yang didasari motif kriminal atau ilegal, tercela, melawan hukum, dan alasan yang tidak dapat dipertanggungjawabkan, termasuk didalamnya penyalahgunaan melalui jaringan internasional atau internasional net working yang dikenal dengan cyber crime. Hal ini, salah satu bentuk kejahatan siber atau cyber crime [3], sebagaimana bentuk kejahatan siber seks atau cyber sex melalui penyebarluasan sarana pornografi/pornoaksi dengan gambar, film, teks, dan lain lain, termasuk di dalamnya cyber (child) pornography, cyberporn, cyberlover, cyberromance, sex on line, dan lain lain).

Keberadaan pornografi/pornoaksi siber telah dirumuskan dalam perundang undangan pidana, baik ketentuan dalam KUHP ataupun ketentuan perundang undangan di luar KUHP. Walaupun demikian, perundang undangan pidana terkait dengan pornografi/pornoaksi siber, baik dalam lingkup kebijakan formulasi (dimungkinkan ada nya ketidak-konsistenan, ketidak-tegasan/ ketidak-jelasan, atau ke-vakuman hukum) ataupun dalam lingkup kebijakan yudisial (dimungkinkan adanya berbagai interpretasi terhadap ketentuan undang undang). Oleh karena itu, hakekat keberadaan kebijakan formulasi dan kebijakan yudisial tidak lain yang diarahkan pada hakekat, realita, dan pengaturan tindak pidana pornografi di Indonesia dalam upaya penanggulangan pornografi diera siber.

Dengan memperhatikan berbagai isu hukum dalam uraian terdahulu, maka permasalahan yang muncul dalam penelitian hukum ini, yang meliputi:

1. Apa hakekat pengaturan tindak pidana Pornografi di Indonesia ?

2. Bagaimana realita putusan lembaga peradilan di Indonesia terhadap tindak pidana pornografi ? 3. Bagaimana seharusnya pengaturan tindak pidana pornografi dalam upaya menanggulangi pornografi diera siber di Indonesia?

\section{METODE PENELITIAN}

Jenis penelitian termasuk dalam lingkup hukum normatif atau normatif yuridis; sedangkan pendekatan dalam penelitian hukum ini melalui peraturan perundang undangan atau statute approach [4], sebagaimana perundang undangan terkait dengan pornografi/pornoaksi siber; pendekatan kasus atau case approach [4], sebagaimana putusan lembaga peradilan terkait dengan pornografi/pornoaksi siber; dan pendekatan konsep atau conseptual approach [4], sebagaimana konsep terkait dengan istilah dan pengertian kesusilaan, pornografi/ pornoaksi, dan menimbulkan nafsu birahi para pemuda.

Bahan dalam penelitian hukum normatif [5], yang meliputi bahan hukum primer, sekunder, dan tersier. Hal ini, keberadaan bahan hukum primer, sebagaimana berbagai ketentuan hukum dalam perundang undangan, antara lain :

1. Kitab Undang undang Hukum Pidana (KUHP) Indonesia;

2. Undang Undang Nomor 44 Tahun 2008 tentang Pornografi;

3. Undang Undang Nomor 11 Tahun 2008 tentang Informasi dan Transaksi Elektronik;

4. Convention on Cyber Crime Tahun 2001, Budapest - Hungaria;

Kemudian, keberadaan bahan hukum sekunder, sebagaimana uraian dalam berbagai literatur terkait dengan "kejahatan kesusilaan (ponografi/pornoaksi siber)". Demikian pula, keberadaan bahan hukum tersier, sebagaimana uraian dalam berbagai kamus atau dictionary terkait dengan "kejahatan kesusilaan (ponografi/pornoaksi siber)".

\section{Metode Pengumpulan Data}

Pengumpulan bahan dalam penelitian hukum normatif melalui identifikasi dan klasifikasi berbagai ketentuan dalam perundang undangan terkait dengan "kejahatan kesusilaaan (pornografi/pornoaksi siber)"; yang diikuti dengan bacaan terhadap berbagai literatur terkait dengan "kejahatan kesusilaaan (pornografi/pornoaksi siber)" tersebut.

Analisis dalam penelitian hukum normatif melalui pemanfaatan analisis substansi atau qontent analysis. Kemudian, diikuti dengan metode interpretasi hukum [6], antara lain metode intepretasi gramatika, intepretasi sistematika, dan intepretasi otentik. Demikian pula, keberadaan asas hukum dalam peraturan perundang undangan [7], selain asas terkait dengan pembentukan hukum serta asas yang terkandung dalam materi muatan peraturan perundang undangan; juga keberadaan asas hukum dan kebijakan hukum dalam peraturan perundang undangan [8] 


\section{HASIL DAN PEMBAHASAN}

Hakekat pengaturan tindak pidana pornografi di Indonesia, yang diawali dengan pengaturan tindak pidana, diikuti dengan tindak pidana pornografi, dan diakhiri dengan hakekat pengaturan tindak pidana pornografi, sebagaimana uraian berikut ini.

Pengaturan tindak pidana sebagai norma, kaidah, atau hukum, yang termasuk sebagai obyek kajian dalam kebijakan formulasi dalam hukum pidana senantiasa terkait dengan salah satu hal mendasar [9] adalah "perbuatan apa yang seharusnya dijadikan tindak pidana" Oleh karena itu, perbuatan apa yang seharusnya dijadikan tindak pidana melalui kriminalisasi serta dekriminalisasi [10], bahwa kriminalisasi sebagai suatu proses penetapan suatu perbuatan sebagai tindak pidana serta diancam dengan pidana yang diakhiri dengan pembentukan dalam perundang undangan; sedangkan dekriminalisasi sebagai suatu proses penetapan suatu perbuatan yang dihilangkan sama sekali sifat dapat dipidananya perbuatan itu. Kemudian, kriminalisasi terkait dengan politik kriminal [11], bahwa kriminalisasi sebagai suatu perbuatan yang harus sesuai dan sejalan dengan politik kriminal Bangsa Indonesia, sebagaimana bentuk perbuatan yang bertentangan dengan nilai nilai fundamental dalam kehidupan masyarakat serta dianggap patut untuk dihukum dalam upaya menyelenggarakan kesejahteraan masyarakat. Oleh karena itu, suatu bentuk perbuatan yang bertentangan dengan nilai nilai fundamental dalam kehidupan masyarakat serta dianggap patut untuk dihukum sesuai dan sejalan dengan keberadaan sifat melawan hukum dari suatu perbuatan [12], antara lain bentuk sifat melawan hukum materiil, selain diarahkan pada rumusan dalam ketentuan perundang undangan juga bertentangan dengan nilai nilai yang hidup dalam masyarakat.

Tindak pidana pornografi sebagai salah satuk bentuk norma, kaidah, atau hukum yang dirumuskan dalam perundang undangan pidana, baik ketentuan dalam KUHP ataupun ketentuan dalam perundang undangan di luar KUHP, sebagaimana bentuk tindak pidana pornografi/pornoaksi dan dalam perkembangannya menjadi tindak pidana pronografi / pornoaksi siber.

Keberadaan pornografi [13] berasal dari pornos sebagai pelanggaran kesusilaan atau cabul serta grafi sebagai tulisan, gambar, dan patung, sehingga pornografi sebagai bentuk tindak pidana dalam lingkup kesusilaan (pasal
282 dan 283 bis KUHP serta pasal 532 dan 533 KUHP); yang diikuti dengan pandangan HB Jassin [14], bahwa pornografi sebagai tulisan atau gambaran dengan maksud sengaja untuk merangsang seksual; yang membuat fantasi pembaca berangan angan kearah kelamin serta menyebabkan nafsu birahi bergelora. Demikian pula, pandangan Arief Budiman [14], bahwa pornografi sebagai sesuatu yang berhubungan dengan persoalan seksual yang tidak pantas diungkapkan secara terbuka kepada umum.

Ketentuan hukum tentang pornografi dalam KUHP, yang dirumuskan melalui Pasal 282 ayat (1) terkait dengan “...menyiarkan, mempertunjukkan atau menempelkan di muka umum tulisan, gambaran atau benda, yang telah diketahui dan yang melanggar kesusilaan; atau barangsiapa dengan maksud untuk disiarkan, dipertunjukkan atau ditempelkan di muka umum, memasukkannya ke dalam negeri, meneruskannya, mengeluarkannya dari negeri, atau mempunyainya dalam persediaan; ataupun secara terang-terangan atau dengan mengedarkan surat tanpa diminta, menawarkannya atau menunjuknya sebagai bisa didapat ...."; Pasal 282 ayat (2) terkait dengan " ...jika ada alasan kuat baginya untuk menduga, bahwa tulisan, gambaran atau benda itu melanggar kesusilaan menyiarkan, mempertunjukkan atau menempelkan dimuka umum tulisan, gambaran atau benda yang melanggar kesusilaan, ataupun barangsiapa, dengan maksud untuk disiarkan, dipertunjukkan atau ditempelkan dimuka umum, membikinnya, memasukkannya ke dalam negeri, meneruskan, mengeluarkannya dari negeri, atau mempunyai dalam persediaan, ataupun barangsiapa, secara terang-terangan atau dengan mengedarkan surat tanpa diminta, menawarkan atau menunjuknya sebagai bisa didapat ..."; dan Pasal 282 ayat (3) terkait dengan pornografi secara tulisan atau isan sebagai mata pencaharian atau kebiasaan; yang diikuti dengan Pasal 533 terkait dengan gambaran atau benda, yang mampu membangkitkan nabsu birahi para pemuda. Kemudian, ketentuan hukum tentang pornografi dalam UU Nomor 44 Tahun 2008 tentang Pornografi, yang dirumuskan melalui Pasal 1 terkait dengan batasan pornografi, yang meliputi "gambar, sketsa, ilustrasi, foto, tulisan, suara, bunyi, gambar bergerak, animasi, kartun, percakapan, gerak tubuh, atau bentuk pesan lainnya melalui berbagai bentuk media komunikasi dan/atau pertunjukan dimuka umum, yang membuat kecabulan atau eksploitasi 
seksual yang melanggar norma kesusilaan dalam masyarakat"; yang diikuti dengan Pasal 4 ayat (1) terkait dengan "pornografi yang secara eksplisit memuat persenggamaan, termasuk persenggamaan yang menyimpang; kekerasan seksual; masturbasi atau onani; ketelanjangan atau tampilan yang mengesankan ketelanjangan; alat kelamin; atau pornografi anak. Demikian pula, ketentuan dalam UU Nomor 11 Tahun 2008 tentang Informasi dan Transaksi Elektronik yang dirumuskan melalui Pasal 27 ayat (1) terkait dengan "mendistribusikan dan/ atau mentransmisikan dan/ atau membuat dapat diaksesnya informasi elektronik dan/atau dokumen elektronik yang memiliki muatan yang melanggar kesusilaan;

Dengan memperhatikan ketentuan Pasal 282 dan Pasal 533 KUHP, Pasal 1 angka 1 dan Pasal 4 ayat (1) UU Nomor 44 Tahun 2008 tentang Pornografi, dan Pasal 27 ayat (1) UU Nomor 11 Tahun 2008 tentang Informasi dan Transaksi Elektronik, selain ditemukan istilah dan pengertian pornografi dengan ruang lingkupnya yang melanggar nilai nilai Pancasila sebagai dasar dan ideologi negara Indonesia, terutama nilai nilai Ketuhanan Yang Maha Esa, kemanusiaan yang adil dan beradab, dan keadilan sosial bagai seluruh rakyat Indonesia; juga ditemukan adanya perbedaan di antara istilah dan pengertian melanggar kesusilaan, membangkitkan nafsu birahi pemuda, atau pornografi.

Hakekat pengaturan tindak pidana pornografi senantiasa terkait dengan pemberantasan tindak pidana pornografi/ pornoaksi siber; pencegahan tindak pidana pornografi/ pornoaksi siber, baik sebagai tindak pidana ataupun sebagai pemicu tindak pidana lainnya; dan perlindungan korban serta masyarakat dari tindak pidana pornografi/ pornoaksi siber serta pelaku tindak pidana pornografi/ pornoaksi siber, sebagaimana uraian berikut ini.

Upaya pemberantasan tindak pidana pornografi/ pornoaksi siber sebagai bentuk ketahanan terhadap realita kejahatan. Hal ini, upaya pemberantasan tindak pidana pornografi/ pornoaksi siber melalui berbagai putusan lembaga peradilan, sebagaimana uraian realita putusan lembaga peradilan di Indonesia terhadap tindak pidana pornografi.

Upaya pencegahan tindak pidana pornografi/ pornoaksi siber (tindak pidana ataupun sebagai pemicu tindak pidana lainnya) sebagai bentuk ketahanan terhadap potensi kejahatan pornografi/ pornoaksi siber yang mungkin muncul atau tindak pidana lain sebagai akibat tindak pidana pronografi/ pornoaksi siber tersebut. Hal ini, kemunculan berbagai tindak pidana lain yang dipicu tindak pidana pornografi/ pornoaksi siber, antara lain :

a. Kejahatan kesusilaaan dalam KUHP melalui perzinahan (pasal $284 \mathrm{KUHP}$ ); perkosaan (pasal 285 KUHP); persetubuhan di luar perkawinan dengan seorang wanita dalam keadaan pingsan / tidak berdaya ; belum berumur 15 tahun; atau belum mampu dikawin (pasal 286, 287, dan 288 KUHP); perbuatan cabul dengan kekerasan/ ancaman kekerasan/ membiarkannya; seseorang dalam keadaan pingsan/ tidak berdaya; belum berumur 15 tahun; atau belum mampu dikawin; membujuk seseorang belum berumur 15 tahun atau belum mampu dikawin; atau melakukan / membiarkan dilakukan persetubuhan di luar perkawinan (pasal 289 dan 290 KUHP); perbuatan cabul dengan sesama jenis kelamin; sesama jenis kelamin yang belum cukup umur; atau perbuatan cabul dengan memberi janji uang atau barang; menyalahgunakan wibawa; penyesatan dengan sengaja menggerakan seseorang yang belum cukup umur (pasal 292 dan 293 KUHP); perbuatan cabul dengan anaknya, anak tiri, anak angkat, anak dibawah pemeliharanya, atau bujangnya; dengan sengaja menghubungkan atau memudahkan dilakukannya perbuatan cabul oleh anaknya, anak tiri, anak angkat, anak dibawah pemeliharanya, yang belum cukup umur; jika dilakukan sebagai mata pencaharian atau kebiasaan (pasal 294 dan 295 KUHP);

b. Kejahatan kesusilaan di luar KUHP, antara lain kekerasan dalam rumah tangga (pasal 5 dan pasal 8 UU Nomor 23 Tahun 2004 tentang Penghapusan Kekerasan Dalam Rumah Tangga); perdagangan orang (pasal 12 UU Nomor 21 Tahun 2007 tentang Pemberantasan Tindak Pidana Perdagangan Orang); Informasi dan Transaksi Elektronik (pasal 27 ayat (1) dan pasal 52 ayat (1) UU Nomor 11 Tahun 2008 tentang Informasi dan Transaksi Elektronik; dan tindak pidana pornografi anak (pasal 9 Convention on Cyber Crime Tahun 2001, Budapest - Hungaria). Upaya perlindungan korban serta masyarakat dari tindak pidana pornografi/ pornoaksi siber serta pelaku tindak pidana pornografi / pornoaksi siber yang keseluruhannya sebagai bentuk ketahanan manusia secara mandiri dan/ atau manusia sebagai anggota masyarakat secara bersama sama melalui bentuk ketahanan agama dan moral, mental dan ideologi, ekonomi, sosial dan budaya, dan intervensi global. Hal ini, ketahanan manusia secara mandiri dan/ atau manusia sebagai anggota masyarakat secara 
bersama sama untuk mengetahui, memahami, menghayati, dan mengaktualisasi nilai nilai Pancasila sebagai dasar dan ideologi masyarakat, bangsa, dan negara Indonesia, terutama keberadaan nilai dasar Ketuhanan Yang maha Esa, kemanusiaan yang adil dan beradab, dan keadilan sosial bagi seluruh rakyat Indonesia.

Putusan lembaga peradilan di Indonesia terhadap tindak pidana pornografi.Keberadaan putusan peradilan di Indonesia terhadap tindak pidana pornografi. senantiasa terkait dengan kebijakan judisial dalam hukum pidana. Hal ini, keberadaan hakekat pengaturan pornografi yang dirumuskan dalam perundang undangan tentang pornografi di Indonesia termasuk dalam lingkup das sollen. Berlainan dengan penerapan perundang undangan melalui putusan lembaga peradilan di Indonesia terhadap tindak pidana pornografi termasuk dalam lingkup das sein.

Keberadaan sejauh mana hakekat pengaturan tindak pidana pornografi melalui perundang undangan (das sollen) dapat diterapkan melalui putusan lembaga peradilan di Indonesia terhadap tindak pidana pornografi (das sein) dapat diketahui dan dipahami melalui berbagai putusan lembaga peradilan di Indonesia, yang meliputi :

a. Putusan Pengadilan Negeri Jakarta Utara Nomor 459 / Pid Sus / 2012 / PN Jkt Ut. terhadap terdakwa "W alias B" terkait dengan ketentuan Pasal 29 jo Pasal 4 UU Nomor 44 Tahun 2008 tentang Pornografi; sedangkan dasar pertimbangan yang dipergunakan hakim pada lembaga pengadilan tersebut sebagai hal yang memberatkan adalah melanggar norma agama; b. Putusan Pengadilan Negeri Bandung Nomor 1402 / Pid B / 2010 / PN Bdg. serta Putusan Pengadilan Tinggi Bandung Nomor 68 / Pid / 2011 /PT Bdg. terhadap terdakwa "RS alias R bin IS" terkait dengan ketentuan Pasal 29 UU Nomor 44 Tahun 2008 tentang Pornografi jo Pasal 56 ayat (2) KUHP; sedangkan dasar pertimbangan yang dipergunakan hakim pada lembaga pengadilan tersebut sebagai hal yang memberatkan adalah tersebar luas dan dapat diakses untuk dilihat/ditonton oleh siapapun, termasuk anak anak remaja yang masih dibawah umur, yang dapat merusak moral anak bangsa;

c. Putusan Pengadilan Negeri Sleman Nomor 476 / Pid Sus / 2013 / PN SImn. terhadap terdakwa "HJ bin IHS" terkait dengan ketentuan Pasal 45 ayat (1) jo Pasal 27 ayat (1) UU Nomor 11 Tahun 2008 tentang Informasi Transaksi Elektronik; sedangkan dasar pertimbangan yang dipergunakan hakim pada lembaga pengadilan tersebut sebagai hal yang memberatkan adalah mempengaruhi nilai moral, akhlak, dan kepribadian generasi muda;

d. Putusan Pengadilan Negeri Surabaya Nomor 320 / Pid B / 2011 / PN Sby. terhadap terdakwa "JIJ alias BS" terkait dengan ketentuan Pasal 29 jo Pasal 4 UU Nomor 44 Tahun 2008 tentang Pornografi; sedangkan dasar pertimbangan yang dipergunakan hakim pada lembaga pengadilan tersebut sebagai hal yang memberatkan adalah merusak mental generasi muda.

Dengan memperhatikan berbagai putusan lembaga peradilan, bahwa keseluruhan dasar pertimbangan yang memberatkan diarahkan pada melanggar norma agama, mempengaruhi nilai moral, akhlak, dan kepribadian generasi muda, merusak mental generasi muda; merusak moral anak bangsa, yang tersebar luas dan dapat diakses untuk dilihat/ ditonton oleh siapapun, termasuk anak anak remaja yang masih dibawah umur.

Pengaturan tindak pidana pornografi dalam upaya penanggulangan pornografi era siber di Indonesia.

Pengaturan tindak pidana pornografi dalam upaya penanggulangan pornografi era siber di Indonesia. Hal ini, kebijakan formulasi melalui lembaga pembentuk undang undang dengan kegiatan pembentukan hukum atau rechts forming dengan tetap memperhatikan :

a. hakekat nilai nilai Pancasila sebagai dasar dan ideologi negara Indonesia yang diikuti dengan ketahanan manusia secara mandiri dan/ atau manusia sebagai anggota masyarakat (ketahanan moral dan agama, mental dan ideologi, ekonomi, sosial dan budaya, dam intervensi global); ketahanan terhadap realita kejahatan (pemberantasan tindak pidana pronografi/ pornoaksi siber); dan ketahanan terhadap potensi kejahatan yang mungkin muncul (tindak pidana pornografi/ pornoaksi siber sebagai pemicunya);

b. dinamika ilmu pengetahuan dan teknologi yang dihadapi masyarakat, bangsa, negara Indonesia dalam pergaulan bangsa bangsa di dunia, terutama pemanfaatan ilmu pengetahuan dan teknologi yang berbasis teknologi informasi dan komunikasi;

c. asas asas hukum dalam peraturan perundang undangan, terutama konsistensi serta kejelasan / ketegasan subtansi dalam peraturan perundang undangan, sehingga terhindar dari berbagai intepretasi hukumnya (konsistensi dari berbagai istilah dan pengertian kesusilaan, 
membangkitkan nafsu birahi pemuda dan pornografi.

Berlainan dengan kebijakan yudisial melalui lembaga peradilan dengan kegiatan penemuan hukum atau rechts vinding dengan berbagai interpretasi hukum terhadap realita tindak pidana pornografi/ pornoaksi siber yang dihadapinya. Oleh karena itu, di antara kebijakan formulasi di satu sisi dengan kebijakan yudisial di sisi lain terdapat suatu hubungan timbal balik dalam upaya perwujudan hakekat pengaturan tindak pidana pornografi/ pornoaksi siber di Indonesia.

Dengan demikian, pengaturan tindak pidana pornografi dalam upaya penanggulangan pornografi era siber di Indonesia diperlukan adanya suatu keharusan, bahwa pengaturan tindak pidana pornografi/ pornokasi siber di Indonesia senantiasa memenuhi keberlakuan hukum secara filosofis, sosiologis, dan yuridis terkait dengan dinamika ilmu pengetahuan dan teknologi, terutama teknologi informasi dan komunikasi dengan berbagai dampak positif atau negatif yang mungkin muncul di masa masa mendatang.

\section{KESIMPULAN}

Kesimpulan yang diperoleh terhadap temuan dalam penelitian hukum normatif ini, yang meliputi :

a. Hakekat pengaturan tindak pidana pornografi yang diarahkan pada nilai nilai Pancasila sebagai dasar dan ideologi negara; ketahanan manusia secara mandiri dan/atau manusia sebagai anggota masyarakat secara bersama sama melalui bentuk ketahanan moral dan agama, mental dan ideologi, ekonomi, sosial dan budaya, dam intervensi global; ketahanan terhadap realita kejahatan sebagai bentuk upaya pemberantasan tindak pidana pronografi/ pornoaksi siber; dan ketahanan terhadap potensi kejahatan yang mungkin muncul sebagai akibat realita tindak pidana pronografi/pornoaksi siber sebagai pemicunya;

b. Realita putusan lembaga peradilan, bahwa keseluruhan dasar pertimbangan hakim yang diarahkan pada melanggar norma agama, mempengaruhi nilai moral, akhlak, dan kepribadian generasi muda, merusak mental generasi muda; merusak moral anak bangsa, yang tersebar luas dan dapat diakses untuk dilihat/ ditonton oleh siapapun, termasuk anak anak remaja yang masih dibawah umur.

c. Pengaturan tindak pidana pornografi dalam upaya penanggulangan pornografi era siber di
Indonesia melalui kebijakan formulasi dan kebijakan yudisial dalam upaya perwujudan hakekat pengaturan tindak pidana pornografi/ pornoaksi siber di Indonesia, yang diikuti dengan dinamika ilmu pengetahuan dan teknologi (teknologi informasi dan komunikasi) serta keberadaan asas asas hukum dan kebijakan hukum dalam peraturan perundang undangan.

\section{SARAN}

Saran yang disampaikan terkait dengan temuan dalam penelitian hukum normatif ini, yang meliputi :

a. Kebijakan formulasi melalui perumusan perundang undangan terkait dengan pornografi/ pornoaksi siber senantiasa tetap memperhatikan hakekat pengaturan tindak pidana pornografi di Indonesia (nilai nilai Pancasila sebagai dasar dan ideologi negara Indonesia; ketahanan manusia secara mandiri dan/atau manusia sebagai anggota masyarakat (ketahanan moral dan agama, mental dan ideologi, ekonomi, sosial dan budaya, dam intervensi global); ketahanan terhadap realita kejahatan (pemberantasan tindak pidana pronografi/ pornoaksi siber); dan ketahanan terhadap potensi kejahatan yang mungkin muncul (tindak pidana pronografi/ pornoaksi siber sebagai pemicu berbagai tindak pidana lain);

b. Kebijakan formulasi melalui perumusan perundang undangan terkait dengan pornografi/ pornoaksi siber, selain tetap memperhatikan dinamika ilmu pengetahuan dan teknologi, terutama pemanfaatan teknologi informasi dan komunikasi; juga tetap memperhatikan asas asas hukum dan kebijakan hukum dalam peraturan perundang undangan, terutama konsistensi dari berbagai istilah dan pengertian kesusilaan, membangkitkan nafsu birahi pemuda dan pornografi.

\section{UCAPAN TERIMA KASIH}

Ucapan terima kasih disampaikan kepada Direktorat Penelitian dan Pengabdian Kepada Masyarakat, Direktorat Jenderal Pembelajaran dan Kemahasiswaan, Kementerian Riset, Teknologi dan Pendidikan Tinggi yang telah memberikan fasilitas serta bantuan dana untuk penelitian unggulan perguruan tinggi, Rektor dan staf Universitas Brawijaya yang telah memberikan fasilitas serta bantuan dana untuk penelitian unggulan perguruan tinggi; dan Dekan serta staf Fakultas hukum Universitas Brawijaya 
yang telah memberikan fasilitas untuk kelancaran

dalam penelitian unggulan perguruan tinggi.

\section{DAFTAR PUSTAKA}

[1]. Suharto, 1995, Bioteknolgi Dalam Dunia Industri, Andi Offset, Yogyakarta

[2]. Rahardja, Satjipta, 1979, Hukum dan Perubahan Sosial, Alumni, Bandung

[3]. Wisnubroto, Al, 2010, Strategi Penanggulangan Kejahatan Telematika, Universitas Atma Jaya, Yogyakarta

[4]. Mahmud Marzuki, Peter, 2008, Penelitian Hukum, Kencana Prenada Media Group, Jakarta

[5]. Soekanto, Soerjono dan Mamudji, Sri, 1986, Penelitian Hukum Normatif, Rajawali, Jakarta

[6]. Bakti, Yudha, 2008, Penafsiran dan Konstruksi Hukum, Alumni, Bandung

[7]. Natabaya, HAS, 2008, Sistem Peraturan Perundang undangan Indonesia, Konstitusi Press, Jakarta

[8]. Lembaga Administrasi Negara Republik Indonesia, 1994, Sistrem Administrasi Negara Republik Indonesia, Jilid II, Haji Masagung, Jakarta

[9]. Muladi dan Barda Nawawi Arif, 1984, Teori teori dan Kebijakan Pidana, Alumni, Bandung

[10]. Sudarto, 1981, Hukum dan Hukum Pidana, Alumni, Bandung

[11]. Badan Pembinaan Hukum Nasional, 1980, Simposium Pembaharuan Hukum Pidana Nasional, Jakarta

[12]. Muljatno, 2009, Asas Asas Hukum Pidana, Rineka Cipta, Jakarta

[13]. Wirjono Prodjodikoro, 1980, Tindak tindak Pidana Tertentu Di Indonesia, Eresco, Jakarta

[14]. Tjita Lesmana, 1995, Pornografi Dalam Media Massa, Puspa Swara, Jakarta 